\title{
Prevalence and antibiotic susceptibility pattern of bacteriuria among HIV-seropositive patients attending the Bamenda Regional Hospital, Cameroon
}

\author{
Moses Samje ${ }^{1}$, Onesimus Yongwa ${ }^{2}$, Alice Mbi Enekegbe ${ }^{2}$, Simon Njoya ${ }^{3}$
}

1. Department of Biomedical Science, Faculty of Health Sciences, University of Bamenda, Cameroon.

2. Department of Medical Laboratory Science, Faculty of Health Sciences, University of Bamenda, Cameroon.

3. Microbiology Laboratory, Bamenda Regional Hospital, Cameroon.

\section{Author details:}

Moses Samje: msamje@gmail.com, Tel: +237 677679 112;, Onesimus Yongwa: oyongwa898@gmail.com, Tel: +237 673333 892; Mbi Alice Enekegbe: enekegbe2000@yahoo.com/mbialiceenekegbe@gmail.com, Tel: +237 678332 504; Simon Njoya: simon.njoya.m@gmail.com, Tel: +237 674628373

\begin{abstract} bacteria isolates among HIV patients. method was used to assess susceptibility to antimicrobial agents. Enterococcus and Proteus showing 100\% resistance to this drug.

DOI: https://dx.doi.org/10.4314/ahs.v20i3.7 v20i3.7

\section{Introduction}

HIV remains a major global public health issue with the sub-Saharan Africa being the most affected with over 25.7 million people living with HIV/AIDS as of $2017^{1}$. Infection with HIV progressively reduces the effectiveness of the immune system rendering the individual vulnerable to opportunistic infections and cancers ${ }^{1}$. Urinary tract infections (UTIs) have been reported to
\end{abstract}

Background: HIV causes a decrease in CD4+ lymphocyte cells count, exposing the individual to infections (urinary tract infections). This study was carried out to determine the prevalence of bacteriuria and antimicrobial susceptibility pattern of

Methods: Clean catch mid-stream urine samples were collected from 135 HIV- seropositive patients, cultured on Cystein lactose electrolyte deficient (CLED) agar and incubated at $37^{\circ} \mathrm{C}$ for 24 hours. The modified Kirby-Bauer's disc diffusion

Results: The prevalence of bacteriuria was 67.4\% (91/135). Staphylococcus aureus was the most predominant (42.9\%) isolate, followed by Escherichia. coli (24.2\%), then Coagulase negative Staphylococci (10.9\%). The highest proportion of bacteria was isolated from patients having a CD4+ T-cell count of less than 300 cells $/ \mathrm{mm}^{3}(39.6 \%)$. There was an association between the level of $\mathrm{CD} 4+$ cell count and bacterial urinary tract infection $(\mathrm{P}=0.001)$. Most sensitive drugs were gentamycin, vancomycin and amoxicillin-clavulanic acid while the drug with the greatest resistance was sulphamethoxazole-trimethoprim, with

Conclusion: Bacteriuria and resistance to commonly used antibiotics is prevalent among HIV/AIDS patients attending the Bamenda Regional Hospital. Therapy based on antimicrobial susceptibility test is encouraged.

Keywords: Bacteriuria; HIV-seropositive patients; susceptibility; CD4+ T-cell.

Cite as: Samje M, Yongwa O, Enekegbe AM, Njoya S. Prevalence and antibiotic susceptibility pattern of bacteriuria among HIV-seropositive patients attending the Bamenda Regional Hospital, Cameroon. Afri Health Sci. 2020;20(3): 1045-1052. bttps:// dx.doi.org/10.4314/abs.

\footnotetext{
Corresponding author:

Moses Samje,

Department of Biomedical Science,

Faculty of Health Sciences,

University of Bamenda, Cameroon.

Tel: +237677679112

E-mail:msamje@gmail.com
}

be among the most common infectious diseases for which patients seek medical treatment with an estimated incidence of 250 million annually ${ }^{2,3}$. Patients with low CD4+lymphocyte cell count are at risk of having some neurological symptoms which lead to urinary stasis and ultimately, infection. In addition, women, infants, the elderly, HIV/AIDS patients and those with underlying urological abnormalities are at increased risk of UTIs ${ }^{4}$. According to Njunda and others ${ }^{5}$, Gram negative bacteria including Escherichia coli, Klebsiella pneumoniae, Enterobacter aerogenes, Enterobacter cloacae, and Serratia marcescens were responsible for most UTIs. The association between the incidence of bacteriuria and CD4+ T-cell counts has been conflicting. While some findings revealed a higher frequency of UTI among HIV-seropositive patients, others showed no correlation between the two infections ${ }^{5,6,15}$. 
The inevitable emergence and rise of antibiotic resistance in the management of urinary tract infections is a serious public health problem globally and especially in the developing countries. Common causes of resistance to antibiotics include their frequent use and misuse and the transmission of resistant bacteria strains from one individual to another ${ }^{7}$. The availability of just few antimicrobial agents leave clinicians with a limited number of antimicrobial agents to fight infection. This ultimately leads to drug pressure which can easily give rise to sub-optimal response or ineffectiveness to the commonly available antibiotics ${ }^{8}$. In order to effectively tackle this rising antibacterial resistance, WHO recommends the putting in place of surveillance system for the collection of information. This will entail that a country, amongst others get information on the trend in resistance, monitor the impact of intervention and inform treatment guidelines ${ }^{8}$.

Akoachere and others ${ }^{9}$ reported that information on the pattern of resistance to community acquired uropathogens have not been extensively studied in Cameroon. Antimicrobial susceptibility testing (AST) is important in deciding the appropriate antimicrobial agent to be used for treatment. Unfortunately, the high cost of culture precludes the routine dependence on AST prior to prescription and treatment. In effect, the majority of treatment relies on the result of urinalysis and urine microscopy. The information gotten from these diagnostic methods is limited in guiding the clinician onhe ideal antimicrobial agent for a specific infection. This empiric practice could predispose the community to treatment failure and equally give rise to resistance. This study was therefore aimed at determining the etiologic agents of bacteriuria among HIV- seropositive patients and their antimicrobial susceptibility pattern to commonly used antibiotics as well as assessing the relationship between CD4+ T-cell counts and bacteriuria in these patients attending the Bamenda Regional Hospital.

\section{Materials and methods \\ Study design}

This was a cross-sectional hospital-based study carried out at the HIV/AIDS treatment center of the Bamenda Regional Hospital in the North West Region of Cameroon. People living with HIV/AIDS (PLWHIV/AIDS) attending the Treatment Center were recruited for this study. We excluded those who were already on antibiotic therapy. Information on socio-demographic characteristics, treatment status and the presence of signs and symptoms of urinary tract infection was obtained from the patient's record and interview.

\section{Laboratory analyses}

About forty milliliters of clean catch mid-stream urine specimen was collected from each participant using a sterile wide mouth container, avoiding all contaminations. The samples were brought to laboratory within 30 minutes of collection for microscopy, culture and subsequent antibiotic susceptibility testing. CD4+T-cell counts was done using blood samples collected from all those who gave urine samples and analysed using Alere PimaTM(Alere Technologies GmbH, Germany).

In the laboratory, samples were inoculated unto Cystein lactose electrolyte deficient (CLED) agar plates using a $0.01 \mathrm{ml}$ loop, and incubated at $37^{\circ} \mathrm{C}$ for 24 hours. Following current guidelines which indicates that for a single isolate a density of $10^{5} \mathrm{CFU} / \mathrm{ml}$ indicates infection after 24 hours coupled with the number of distinct colonies ranging from 30-300, the bacterial species was identified and antibiotic susceptibility done ${ }^{10}$. Examination of culture plates were done after 24 hours of incubation. Following significant detection of growth, the bacteria species were first identified morphologically/ span> by their presentation on CLED agar, followed by Gram stain and biochemical testing (coagulase, catalase, oxidase).

The modified Kirby Bauer disc diffusion method was used to do antimicrobial sensitivity test on the different bacteria isolated ${ }^{11,12}$. The following antibiotics (commonly prescribed in our setting for UTI) were used on the isolates were Ceftriaxone $(5 \mu \mathrm{g})$, Amoxicillin-clavulanic acid $(30 \mu \mathrm{g})$, Ciprofloxacin $(5 \mu \mathrm{g})$, Gentamycin (10 $\mu \mathrm{g})$, Vancomycin $(5 \mu \mathrm{g})$, Sulphamethoxazole-Trimethoprim $(10 \mu \mathrm{g})$ and Streptomycin $(10 \mu \mathrm{g})$. The diameters were compared with an interpretative chart and interpreted as sensitive/susceptible, intermediate or resistant. Multidrug resistant bacteria was defined as resistance to three or more antimicrobial classes ${ }^{13}$.

\section{Statistical analysis}

Data was analyzed using IBM SPSS Statistics version 21. Differences in the prevalence of the various bacteria isolated were examined using the Chi-square $\left(\chi^{2}\right)$ test. Difference between variables with p-value less than or equal to 0.05 was considered statistically significant.

\section{Results}

Overall, a total of 135 samples from people living with HIV/AIDS(PLWHIV/AIDS) was analyzed and of these, females $(64.4 \%)$ and those of the age group 41-50 years (39.3\%) constituted the majority, the mean age of study participants was $45.79 \pm 9.255$ standard 
deviation. Most of the 135 participants (68.9\%) were asymptomatic for urinary tract infections and the majority $(40 \%)$ had CD4+ T-cell counts of less than 300 cells $/ \mathrm{mm}^{3}$, the mean CD4 count was $409.24 \pm 196.646$ standard deviation. A total of 131 (97\%) of these 135 subjects were on antiretroviral therapy while 4 were ART naïve.

\section{Prevalence of bacteriuria}

The overall prevalence of bacteriuria among the 135
PLWHIV/AIDS was 67.4\% (91/135). Among these, the majority with positive bacterial culture were female $(86.2 \%)$ and those of the age group greater than 50 years. A significant difference $(\mathrm{p}=0.001)$ was observed in the prevalence among gender and age group. In like manner, a significant difference in positive culture was also noticed among CD4+ T-cell counts. The least infected were those with tertiary level of education, singles and those who had symptoms of UTIs (Table 1). Species of bacteria isolated

Table 1: The Prevalence of bacteriuria among 135 HIV- seropositive patients attending the HIV/AIDS Treatment Centre of the Bamenda Regional Hospital

\begin{tabular}{|c|c|c|c|c|}
\hline Variables & Number (\%) & $\begin{array}{l}\text { Positive Bacteria } \\
\text { culture }(\%)\end{array}$ & $\begin{array}{l}\text { Negative Bacteria } \\
\text { culture }(\%)\end{array}$ & $P$-value \\
\hline \multicolumn{5}{|l|}{ Sex } \\
\hline Male & $48(35.6)$ & $16(33.3)$ & $32(66.7)$ & \multirow[t]{2}{*}{0.001} \\
\hline Female & $87(64.4)$ & $75(86.2)$ & $12(13.8)$ & \\
\hline \multicolumn{5}{|l|}{ Age Range(years) } \\
\hline 20-30 & $7(5.2)$ & $3(42.6)$ & $4(57.1)$ & \multirow{4}{*}{0.001} \\
\hline $31-40$ & $30(22.2)$ & $12(40)$ & $18(60)$ & \\
\hline $41-50$ & $53(39.3)$ & $41(77.4)$ & $12(22.6)$ & \\
\hline $50+$ & $45(33.3)$ & $35(77.8)$ & $10(22.2)$ & \\
\hline \multicolumn{5}{|l|}{ Educational Level } \\
\hline Primary & $88(65.2)$ & $63(71.6)$ & $25(28.4)$ & \multirow{3}{*}{0.096} \\
\hline Secondary & $30(22.2)$ & $18(60)$ & $12(40)$ & \\
\hline Tertiary & $17(12.6)$ & $10(58.8)$ & $7(41.2)$ & \\
\hline \multicolumn{5}{|l|}{ Marital Status } \\
\hline Single & $28(20.7)$ & $14(50)$ & $14(50)$ & \multirow{3}{*}{0.073} \\
\hline Married & $102(75.6)$ & $74(72.5)$ & $28(27.5)$ & \\
\hline Widow/Widower & $5(3.7)$ & $3(60)$ & $2(40)$ & \\
\hline \multicolumn{5}{|l|}{ Symptoms of UTI } \\
\hline Present & $42(31.1)$ & $24(57.1)$ & 18(42.9) & \multirow[t]{2}{*}{0.66} \\
\hline Absent & $93(68.9)$ & $67(72.0)$ & $26(28.0)$ & \\
\hline \multicolumn{5}{|l|}{$\mathrm{CD}_{4}$ cells $/ \mathrm{mm}^{3}$} \\
\hline$<300$ & $54(40)$ & $37(68.5)$ & $17(31.5)$ & \multirow{3}{*}{$\begin{array}{c}0.001 \text { (Odd } \\
\text { Ratio } \\
1.078)\end{array}$} \\
\hline $300-500$ & $50(37)$ & $33(66)$ & $17(34)$ & \\
\hline$>500$ & $31(23)$ & $21(67.7)$ & $10(32.3)$ & \\
\hline \multicolumn{5}{|l|}{ Treatment } \\
\hline On ART & 131(97) & $90(68.7)$ & $41(31.3)$ & \multirow[t]{2}{*}{0.44} \\
\hline ART naïve & $4(3)$ & $2(50)$ & $2(50)$ & \\
\hline
\end{tabular}

The bacteria species isolated were Staphylococcus aureus, Escherichia. coli, Coagulase negative Staphylococci (CONS), Klebsiella spp, Enterococci spp and Proteus spp. Of these species, Staphylococcus aureus was the most predominant (42.9\%), followed by Escherichia coli (24.2\%), then Coagulase negative Staphylococci (CONS) (10.9\%). Overall, Klebsiella spp was $8.8 \%$, while Enterococci spp and Proteus $s p p$ were both $6.6 \%$. The highest number of significant bacteria growths for the six isolated species was observed in female, aged 41-50, married and who have attained only primary level of education (Table 2). Except for $S$. aureus, those with CD4+ T-cell counts less than 300 recorded the highest number of the isolated bacteria (Figure 1). 
Table 2: Distribution of isolated bacteria by socio-demographic characteristics

\begin{tabular}{|c|c|c|c|c|c|c|c|}
\hline \multirow[t]{2}{*}{ Variable } & & \multicolumn{6}{|c|}{ Isolated Bacteria } \\
\hline & & $\begin{array}{l}S . \\
\text { aureus }\end{array}$ & CONS & $\begin{array}{l}\text { E. } \\
\text { coli }\end{array}$ & $\begin{array}{l}\text { Enterococci } \\
\text { spp }\end{array}$ & $\begin{array}{l}\text { Klebsiella } \\
\text { spp }\end{array}$ & $\begin{array}{l}\text { Proteus } \\
\text { spp }\end{array}$ \\
\hline \multirow{2}{*}{ Gender } & Male & 8 & 0 & 6 & 2 & 0 & 0 \\
\hline & Female & 31 & 10 & 16 & 4 & 8 & 6 \\
\hline Age & $20-30$ & 2 & 0 & 0 & 0 & 0 & 1 \\
\hline \multirow[t]{3}{*}{ Range } & $31-40$ & 6 & 0 & 2 & 0 & 4 & 0 \\
\hline & $41-50$ & 20 & 8 & 4 & 4 & 2 & 3 \\
\hline & $50+$ & 11 & 2 & 16 & 2 & 2 & 2 \\
\hline \multirow{3}{*}{$\begin{array}{l}\text { Marital } \\
\text { Status }\end{array}$} & Single & 6 & 2 & 2 & 0 & 4 & 0 \\
\hline & Married & 32 & 8 & 20 & 6 & 4 & 4 \\
\hline & Widow/Widower & 1 & 0 & 0 & 0 & 0 & 2 \\
\hline \multirow{3}{*}{$\begin{array}{l}\text { Level of } \\
\text { Education }\end{array}$} & Primary & 31 & 4 & 16 & 2 & 6 & 4 \\
\hline & Secondary & 6 & 4 & 4 & 2 & 2 & 0 \\
\hline & Tertiary & 2 & 2 & 2 & 2 & 0 & 2 \\
\hline \multirow{6}{*}{$\begin{array}{l}\text { UTI } \\
\text { Symptoms } \\
\text { HIV } \\
\text { status } \\
\text { Treatment }\end{array}$} & Symptomatic & 16 & 2 & 4 & 0 & 2 & 0 \\
\hline & Asymptomatic & 23 & 8 & 18 & 6 & 6 & 6 \\
\hline & $\mathrm{HIV}+$ & 39 & 10 & 22 & 6 & 8 & 6 \\
\hline & HIV naïve & 4 & 1 & 0 & 0 & 1 & 0 \\
\hline & ART & 37 & 10 & 22 & 6 & 8 & 6 \\
\hline & Naïve & 2 & 0 & 0 & 0 & 0 & 0 \\
\hline
\end{tabular}

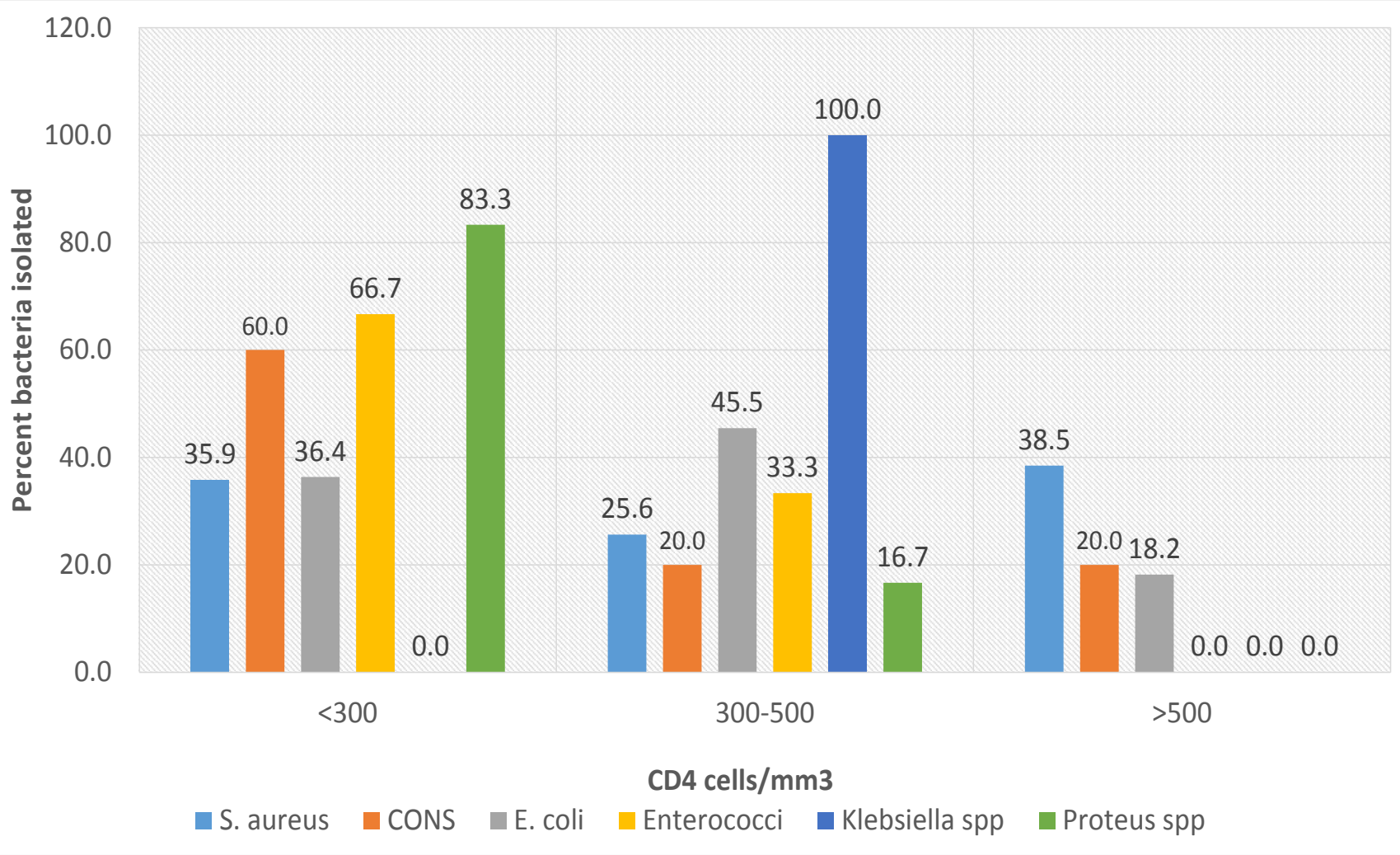

Figure 1: Association between CD4 count and bacteriuria 


\section{a. Antibiotic susceptibility Pattern}

S. aureus was most sensitive to gentamycin and vancomycin with a sensitivity of $84.6 \%$ and $79.5 \%$ respectively. CONS showed the highest sensitivity of $80 \%$ to gentamycin and ceftriaxone while E. coli was most sensitive to gentamycin, ceftriaxone and amoxicillin-clavulanic acid (63.6\%). Proteus spp showed highest sensitivity to vancomycin (83.3\%). As shown in table 3, sulphamethoxazole-trimethoprim recorded the greatest resistance. This drug showed a 100\% resistance to both Enterococcus spp and Proteus spp and 80\% to CONS.

Table 3: Antibiotic Susceptibility pattern of isolated bacteria

\begin{tabular}{|c|c|c|c|c|c|c|c|c|}
\hline $\begin{array}{l}\text { Isolated } \\
\text { Bacteria }\end{array}$ & $\begin{array}{l}\text { Sensitivity } \\
\text { Pattern }\end{array}$ & $\begin{array}{l}\text { CRO } \\
(5 \mu g)\end{array}$ & $\begin{array}{l}\text { AMC } \\
(30 \mu g)\end{array}$ & $\begin{array}{l}\text { CPR } \\
(5 \\
\mu \mathrm{g})\end{array}$ & $\begin{array}{l}\text { GN } \\
(10 \\
\mu \mathrm{g})\end{array}$ & $\begin{array}{l}\mathrm{VA} \\
(5 \mu \mathrm{g})\end{array}$ & $\begin{array}{l}\text { SXT } \\
(10 \\
\mu \mathrm{g})\end{array}$ & $\begin{array}{l} \\
(10 \\
\mu g)\end{array}$ \\
\hline \multirow[t]{3}{*}{ S. aureus } & S & 27 & 25 & 25 & 33 & 31 & 7 & 27 \\
\hline & I & 8 & 8 & 12 & 4 & 4 & 6 & 2 \\
\hline & $\mathrm{R}$ & 4 & 6 & 2 & 2 & 4 & 26 & 10 \\
\hline \multirow[t]{3}{*}{ E. coli } & S & 14 & 14 & 10 & 14 & 12 & 2 & 12 \\
\hline & I & 6 & 0 & 8 & 4 & 4 & 4 & 4 \\
\hline & $\mathrm{R}$ & 2 & 8 & 4 & 4 & 6 & 16 & 6 \\
\hline \multirow[t]{3}{*}{ CONS } & S & 8 & 2 & 6 & 8 & 6 & 0 & 2 \\
\hline & I & 2 & 8 & 2 & 0 & 0 & 2 & 4 \\
\hline & $\mathrm{R}$ & 0 & 0 & 2 & 2 & 4 & 8 & 4 \\
\hline \multirow[t]{3}{*}{ Klebsiella spp } & S & 2 & 6 & 2 & 6 & 6 & 0 & 8 \\
\hline & I & 2 & 0 & 4 & 2 & 2 & 2 & 0 \\
\hline & $\mathrm{R}$ & 4 & 2 & 2 & 0 & 0 & 6 & 0 \\
\hline \multirow{3}{*}{$\begin{array}{l}\text { Enterococcus } \\
\text { spp }\end{array}$} & S & 4 & 4 & 2 & 4 & 4 & 0 & 4 \\
\hline & I & 2 & 2 & 2 & 2 & 2 & 0 & 2 \\
\hline & $\mathrm{R}$ & 0 & 0 & 2 & 0 & 0 & 6 & 0 \\
\hline \multirow[t]{3}{*}{ Proteus spp } & S & 1 & 2 & 0 & 0 & 5 & 0 & 3 \\
\hline & I & 2 & 0 & 1 & 2 & 0 & 0 & 3 \\
\hline & $\mathrm{R}$ & 3 & 4 & 5 & 4 & 1 & 6 & 0 \\
\hline
\end{tabular}

CRO-Ceftriaxone, AMC-Amoxicillin-clavulanic acid, CPR-Ciprofloxacin, GN-Gentamycin, VA-Vancomycin, SXT-Sulphamethoxazole-Trimethoprim, S-Streptomycin.

S- Sensitive, I-Intermediate, R-Resistant.

\section{Discussion}

The prevalence of bacteriuria among people living with HIV/AIDS, attending the HIV/AIDS Treatment Centre was $67.4 \%$ with $S$. aureus being the most encountered bacteria species. Subjects with CD4+ T-cell counts less than 300 cells $/ \mathrm{mm}^{3}$ were more frequently infected and sulphamethoxazole-trimethoprim recorded the greatest resistance to all the isolated bacteria.

Our current findings in this study shows that the prevalence of bacteriuria among HIV-sero patients at the Regional Hospital, Bamenda is higher than those of other studies carried out in Bamenda and Buea ${ }^{5,9}$. The previous studies in Bamenda by Njunda et al focussed solely on coliforms. This could explain the lower prevalence they recorded in their studies almost ten years ago. In a similar study also conducted in both Bamenda and Buea by Akoachere et al., the study participants were not limited to HIV- seropositive patients. Our study has generated data for HIV- seropositive patients in this part of the country where information on bacteriuria among HIV- seropositive patients is scarce. When our findings was compared to those of other countries, the prevalence we recorded is higher than those observed in different parts of Nigeria $(10.9 \%$ and 57.3), Ethiopia (9.2\% and 11.3\%), South Africa (37.6\%)and In$\mathrm{dia}^{3,4,10,14-16}$. Our observation on female being more infected is consistent with almost all the studies we have come across ${ }^{5,6,24}$. This could be explained in part by the relatively short urethra in female whose proximity to the anus predisposes them to infection addition to likely poor behavioural practices. Unlike most of the studies we came across, those of the age group 41-50 years were more infected in our study. Concerning the level of education and bacteria isolated in this study, we observed that those who had attended only primary 
level of education were most infected and those who attended secondary schools might have received basic education on hygiene and risky behaviour thus creating awareness and consequently reducing the risk of infection. This is also in line with our findigs which revealed that those who had attended only primary level of education were the most infected. Contrary to the findings of others in Nigeria and Ethiopia, bacteriuria in asymptomatic patients was higher in our study than their symptomatic counterpart ${ }^{15,17}$.

In this study, $S$. aureus was found to be the most prevalent bacteria species isolated. This is contrary to the findings of Akoachere et al and Njunda et al in both Bamenda and Buea who showed that E. coli was the most frequently encountered bacteria, ${ }^{5,9}$. Our findings however, correlated with those of Murugesh et al in India and Omoregie et al in Nigeria who reported $S$. aureus to be the most frequently encountered bacteria ${ }^{6,15,18}$. Like our study, the latter studies had HIV-seropositive patients as their study participants. Colonization with $S$. aureus has been reported to be a risk factor for subsequent clinical infection in HIV/AIDS patients and the bacteria is an important cause of morbidity and mortality.

With respect to CD4+ T-cell counts, patients with less than 300 cells $/ \mathrm{mm}^{3}$ where more predisposed to UTIs than those who had counts greater than 500 cells $/ \mathrm{mm}^{3}$. This correlates with other studies carried out earlier in the same hospital ${ }^{5}$, and other studies in Tchad ${ }^{19}$, Ethiopia $^{15}$, Bangalore and the Netherlands ${ }^{14,20}$. No relationship, has however, been shown to exist between bacteriuria and CD4+ T-cell counts among HIV-seropositive patients by several other studies carried out in different countries ${ }^{6,21-22}$. A drop in the number of CD4+ T-cells predisposes the immune compromised individual to various opportunistic infections amongst which are UTIs. Accompanying neutropenia to antiretroviral therapy alongside physical and psychological stress could account for this observation. We noticed that patients with CD4+ T-cell counts greater than $500 / \mathrm{mm}^{3}$ were often asymptomatic. This supports the hypothesis that a low CD4+ T- cell count is associated to symptomatic bacteriuria among HIV- seropositive patients in this community.

For all the bacteria species isolated in this study, the drug with the greatest resistance pattern was sulphamethoxazole-trimethoprim, a drug commonly used to treat infections such as urinary tract infections, middle ear in- fections, bronchitis, traveler's diarrhea, and shigellosis. In previous studies carried out in Bamenda, this drug has been reported to show the lowest susceptibility to all the isolated bacteria, ${ }^{5,9}$. Majority of HIV/AIDS patients are placed on this drug when they have cough and it is also a prophylactic treatment against Pneumocystis carinii. The drug is used frequently in the community for auto-medication of common ailments especially stomach disorders and cough. The dose and regimen used in auto-medication is questionable and could expose this community to the acquisition of resistance. The most sensitive drugs; gentamycin, vancomycin and amoxicillin-clavulanic, has also been reported in other studies $^{9,23}$. We also observed that most of the bacteria strains isolated were resistant to two or more antibiotics. This agrees with reports on the emergence of multidrug resistant bacteria strains in the management of UTI among HIV individuals. Antimicrobial resistance is a serious public health problem particularly in developing countries where, lamentably, poverty and ignorance lead to the purchase and use of sub-standard drugs of questionable origin and quality which are in circulation. More so, prescription of antimicrobial agents not based on susceptibility test could facilitate the development of resistance to these commonly and frequently used antibiotics. The upsurge in antibiotic resistance noticed in this study corroborates with earlier work ${ }^{5,15,24}$ where antibiotic abuse and high prevalence of self-medication with antibiotics were identified as being responsible for resistance. The occurrence of multiple drug resistant bacteria in the urine of HIV-seropositive individuals could also significantly increase the risk of opportunistic infections which is less susceptible to antibiotic treatments.

One limitation recognized in this study was the low sample size which can restrain the generalization of our observation. This however, was because we focussed only on HIV patients and not the entire community. The sample size is also a reflection of the study population.

\section{Conclusion}

Our findings showed that more than half of HIV-seropositive patients have bacteriuria with Staphylococcus aureus, Escherichia coli and Coagulase Negative Staphylococci being the most encountered species. Sulphamethoxazole-trimethoprim recorded the greatest resistance pattern to all the isolates tested while Proteus spp and Enterococcus $s p p$ demonstrated the highest multidrug resistance. The indiscriminate use of antibiotics should 
be discouraged and mechanism for the monitoring of antimicrobial resistance be put in place.

List of abbreviations: UTI: urinary tract infection, PLWHIV/AIDS: people living with HIV/AIDS

\section{Declarations}

Ethics approval and consent to participate: Ethical clearance to carry out the study was obtained from the Institutional Review Board (IRB) of the Faculty of Health Sciences (FHS), University of Bamenda (2018/0011/UBa/IRB), while administrative authorizations were gotten from the Regional Delegation of Public Health, North West and from the Director of the Bamenda Regional Hospital. Written informed consent was obtained from each of the study participants.

\section{Consent for publication:}

Not applicable.

\section{Availability of data and material}

The datasets used and/or analyzed during the current study are available from the corresponding author on reasonable request.

\section{Competing interests}

The authors declare that they have no competing interests.

\section{Funding}

Partially supported by research allowance from the University of Bamenda.

\section{Authors' contributions}

MS designed the project, coordinated the study, interpreted the data and drafted the manuscript, OY collected samples, carried out the experiments and drafted the manuscript, MAE drafted the manuscript, SN conducted the experiments, assisted in the interpretation of the susceptibility test. All authors read and approved the final version of the manuscript.

\section{Acknowledgements}

We are grateful to the administration and staff of the Bamenda Regional Hospital for their collaboration in sample collection and logistics put in place. We also acknowledge ITAPS and CV Staff for the sponsorship to attend a manuscript writing workshop.

\section{References}

1. World Health Organization. HIV/AIDS. Available from: http://www.who.int/news-room/fact-sheets/ detail/hiv-aids. Accessed on Oct 6, 2018.

2. Ronald AR, Nicolle LE, Stamm E, Krieger J, Warren J, Schaeffer A, et al. Urinary tract infection in adults: research priorities and strategies. Int J Antimicrob Agents. 2001;17(4):343-8.

3. Beyene G, Tsegaye W. Bacterial Uropathogens in Urinary Tract Infection and Antibiotic Susceptibility Pattern in Jimma University Specialized Hospital, Southwest Ethiopia. EthiopJ Health Sci. 2011; 21(2):141-6.

4. Iweriebor BC, Obi CL, Akinyemi O, Ramalivhana NJ, Hattori T, Okoh AI. Uropathogens isolated from HIV-infected patients from Limpopo Province, South Africa. Afr J Biotechnol. 2012; 11(46):10598-1060410604.

5. L Njunda, H Kamga, J Palle, J Mokube, J Assob Nguedia, E Achidi, S Akuro, J Mbuagbaw, P Ndumbe. Coliforms associated with bacteriuria in Human Immunodeficiency virus (HIV) positive patients attending the Bamenda provincial hospital. J Infect Dis 2009;7(2).

6. R. Omoregie and N. O. Eghafona. Urinary tract infection among asymptomatic HIV patients in Benin city, Nigeria. British Journal of Biomedical Science: 2009; 66(4).

7. Md. Zeyaullah and Vinod Kaul. Prevalence of Urinary Tract Infection and Antibiotic Resistance Pattern in Saudi Arabia Population. Global Journal Biology Agriculture and Health Sciences. 2015; Vol. 4(1):206-214

8. World Health Organization. Antimicrobial Resistance: Global Report on Surveillance. Available from: http:/ / apps.who.int/iris/bitstream/handle/10665/112642/ Accessed on October 2018.

9. Akoachere J-FTK, Yvonne S, Akum NH, Seraphine EN. Etiologic profile and antimicrobial susceptibility of community-acquired urinary tract infection in two Cameroonian towns. BMC Res Notes. 2012;5(1):219.

10. Adekunle O.C, Olowe O.A, Jagunmolu O. Bacteriuria in Apparently Healthy Individual in Osogbo. International Journal of Applied Biology and Pharmacentical Technology. 2013, 4(3)

11. Collee, J.G., R.S. Miles and Watt, B. 1996. Tests for identification of bacteria. In: Collee JG, Duguid JP, Fraser AG, Marmion BP, eds. Mackie and MacCartney Practical Medical Microbiology. 14th ed. New York: USA: Churchill Livingstone; p. 131- 149.

12. British Society for Antimicrobial Chemotherapy Methods for Antimicrobial Susceptibility Testing (2013). Version 7.1 pp 1-87.

13. Magiorakos AP, Srinivasan A, Carey RB, Carmeli Y, Falagas ME, Giske CG et al. Multidrug-resistant, extensively drug-resistant and pandrug-resistant bacteria: 
an international expert proposal for interim standard definitions for acquired resistance. Clin Microbiol Infect. 201218(3):268-81. doi: 10.1111/j.1469-0691

14. K.S R, K.L R, Nimitha J, H.N B. Asymptomatic Bacteriuria In HIV/AIDS Patients: Occurrence and Risk Associated with Low CD4 Counts. J Evol Med Dent Sci. 2013;2(19):3358-66.

15. Fenta GM, Legesse MH, Weldearegay GM. Bacteriuria and their Antibiotic Susceptibility Patterns among People Living with HIV Attending Tikur Anbessa Specialized and Zewditu Memorial Hospital ART Clinics, Addis Ababa, Ethiopia. J Bacteriol Parasitol. 2016;07(05). 16. Akram M, Shahid M, Khan AU. Etiology and antibiotic resistance patterns of community-acquired urinary tract infections in J N M C Hospital Aligarh, India. Ann Clin Microbiol Antimicrob. 2007;6(1):4.

17. Inyang-Eto PC, Udofia GC, Alaribe A. A, Udonwa NE. Asymptomatic Bacteriuria in Patients on Antiretroviral Drug Therapy in Calabar. J Med Sci. 2009;9(6):270 5.

18. Murugesh K, Deepa S, Ravindranath C, Venkatesha D. Multi Drug Resistant Uropathogens in HIV: Are They A Threat to Community? International Journal of Scientific Study. 2014; 2(3):38-42.
19. Abderrazzack AF, Salou M, Patassi A, Yehadji D, Ameyapoh Y. Correlation between Asymptomatic Bacteriuria and HIV-1 Viral Load Level and CD4 Count in Pregnant Women on Antiretroviral Therapy in N'djamena (Chad). World J AIDS. 2015;05:308.

20. Hoepelman AI, van Buren M, van den Broek J, Borleffs JC. Bacteriuria in men infected with HIV-1 is related to their immune status (CD4+ cell count). AIDS. 1992;6(2):179-84.

21. Ojoo J, Paul J, Batchelor B, Amir M, Kimari J, Mwachari $\mathrm{C}$, et al. Bacteriuria in a cohort of predominantly HIV-1 seropositive female commercial sex workers in Nairobi, Kenya. J Infect. 1996;33(1):33-7.

22. Gugino L, Russo T, Wactawski-Wende J, Goodnough SL, Tristram DA, Mylotte J. Asymptomatic bacteriuria in human immunodeficiency (HIV)-infected women. Prim Care Update OBGYNS. 1998;5(4):146.

23. Ifeanyichukwu I. Frequency and Antibiogram of Uropathogens Isolated from Urine Samples of HIV Infected Patients on Antiretroviral Therapy. Am J Biosci. 2013;1(3):50.

24. Kemajou TS, Ajugwo AO. Antibiotic Resistance of Bacterial Isolates from HIV Positive Patients with Urinary Tract Infection (UTI) in Portharcourt, Nigeria. J AIDS Clin Res. 2016;7(8). 